\title{
Aplikasi Varietas Dan Dosis Pupuk Npk Terhadap Produksi Jagung( Zea Mays L. )
}

\author{
Meiyana Hikmawati \\ Dosen Fakultas Pertanian, Universitas Soerjo Ngawi, Jl. Cepu Km.3, Ngawi, 63218 \\ E-mail: -
}

\begin{abstract}
The objectives of this research is Application of variety and NPK fertilizer dosage on the yield of corn (Zea mays L). The method of the research use factorial design based on the Randomized Block Design with two factors of treatment. The first factor was variety : (V1) Pioner, (V2) NK 33, (V3) Pertiwi and second factor was NPK fertilizer dosage : (P0) without fertilizer, (P1) NPK fertilizer dosage 50 g/plot, (P2) NPK fertilizer dosage 100 g/plot, (P3) NPK fertilizer dosage 150 g/plot and each kombination of treatment three times replicated.The result of the research : (1) There was interaction between variety and NPK fertilizer dosage on the parameters of the weight of dry cob per plant . (2) The highest yield was treatment (V3) Pertiwi and (P3) NPK fertilizer dosage 150 g/plotfor all parameters. (3) The highest yield was treatment combination V3 P3 (variety pioner and NPK fertilizer dosage 150 g/plot) providing the best harvest.
\end{abstract}

Keywords - : variety; NPK fertilizer dosage and interaction.

\section{PENDAHULUAN}

Jagung merupakan komoditi pangan terpenting kedua setelah padi karena di beberapa daerah, jagung merupakan bahan makanan pokok. Jagung juga mempunyai arti penting dalam pengembangan industri di Indonesia karena merupakan bahan baku industri pangan maupun pakan ternak khususnya pakan ayam. Dengan semakin berkembangnya industri pengolahan pangan di Indonesia maka kebutuhan jagung akan semakin meningkat pula.

Usaha peningkatan produksi jagung di Indonesia telah digalakkan melalui dua program utama yaitu: (1) ekstensifikasi (perluasan areal) dan (2) intensifikasi (peningkatan produktivitas). Program peluasan areal tanaman jagung selain memanfaatkan lahan kering juga lahan sawah, baik sawah irigasi maupun lahan sawah tadah hujan melalui pengaturan pola tanam.

Pemupukan merupakan salah satu kegiatan yang erat kaitannya dengan pertumbuhan dan produksi tanaman. Ketersediaan pupuk sumber hara N, P, dan K yang lebih direspons oleh tanaman saat ini semakin sulit diperoleh oleh petani, sehingga diperlukan informasi tentang ketersediaan hara di dalam tanah agar diketahui unsur hara yang kahat di tanah tersebut. Kegiatan ini memberikan hasil yang optimal tergantung pada beberapa faktor, di antaranya takaran dan jenis pupuk yang digunakan. Jenis dan takaran pupuk ini banyak digunakan untuk mengkaji tanggap (respons) tanaman terhadap tindakan pemupukan.

Salah satu tanaman yang respons terhadap pemupukan adalah jagung. Jagung merupakan komoditas pertanian yang mendapat perhatian khusus di Indonesia sebab menjadi bahan makanan pokok kedua setelah beras. Jagung membutuhkan unsur hara makro dan mikro. Unsur hara makro yang essensial untuk jagung antara lain nitrogen $(\mathrm{N})$, fosfor $(\mathrm{P})$ dan kalium (K).

Beberapa jenis varietas jagung memiliki respon yang bervariasi terhadap pemupukan $\mathrm{N}, \mathrm{P}$ dan $\mathrm{K}$. Berdasarkan kenyataan tersebut maka perlu dilakukan penelitian tentang dosis pupuk $\mathrm{N}, \mathrm{P}, \mathrm{K}$ dan varietas terhadap pertumbuhan tanaman jagung (Zea mays $L$ ) untuk mengetahui dosis yang tepat dan optimal pada berbagai jenis varietas tanaman jagung.

\section{TINJAUAN PUSTAKA}

\section{A. Klasifikasi dan Morfologi Jagung}

Klasifikasi ilmiah tanaman jagung sebagaimana diketahui adalah:

$\begin{array}{ll}\text { Kerajaan } & \text { : Plantae } \\ \text { Divisio } & : \text { Angiospermae } \\ \text { Kelas } & : \text { Monocotyledoneae } \\ \text { Ordo } & \text { : Poales } \\ \text { Familia } & : \text { Poaceae } \\ \text { Genus } & : \text { Zea } \\ \text { Spesies } & : \text { Zea mays } \mathrm{L} .\end{array}$

Jagung (Zea mays, L) merupakan salah satu tanaman pangan dunia yang terpenting, selain gandum dan padi. Jagung merupakan sumber karbohidrat utama di Amerika Tengah dan Amerika Selatan, selain itu jagung juga menjadi alternatif sumber pangan. Penduduk beberapa daerah di Indonesia (misalnya di Madura dan Nusa Tenggara) juga menggunakan jagung sebagai pangan pokok, selain sebagai sumber karbohidrat, jagung juga ditanam sebagai pakan ternak (hijauan maupun 
Website : http://agritek.unmermadiun.ac.id/index.php/agritek

tongkolnya), diambil minyaknya (dari bulir), dibuat tepung (dari bulir, dikenal dengan istilah tepung jagung atau maizena), dan bahan baku industri (dari tepung bulir dan tepung tongkolnya). Jagung merupakan tanaman semusim (Annual). Satu siklus hidupnya diselesaikan dalam 80-150 hari. Paruh pertama dari siklus merupakan tahap pertumbuhan vegetatif dan paruh kedua untuk tahap pertumbuhan generatif. Tinggi tanaman jagung sangat bervariasi, meskipun tanaman jagung umumnya berketinggian antara $1 \mathrm{~m}$ sampai $3 \mathrm{~m}$, ada varietas yang dapat mencapai tinggi $6 \mathrm{~m}$.

Jagung berasal dari daerah tropis, tapi karena banyak tipe jagung dengan variasi sifat-sifat yang dimilikinya dan sifat-sifat adaptasi yang tinggi maka jagung dapat menyebar luas dan dapat hidup baik diberbagai tipe iklim.

\section{B. Jagung Varietas Pioneer}

Jagung hibrida pioneer merupakan salah satu jagung yang sudah dilakukan penelitian guna peningkatan produkivitas di pusat penelitian pioneer di Negara Thailand dan Philipina. Berdasarkan hasil kegiatan penelitian tersebut, diperoleh jagung hibrida dengan varietasi yang memiliki ciri khas dengan tingkat produktivitas yang tinggi serta tahan terhadap serangan hama dan penyakit. Hal ini adalah keunggulan yang di miliki oleh jagung hibrida. Tidak hanya itu, keistimewaan lainnya yaitu, jagung hibrida memiliki tongkol jagung yang kecil, namun biji jagung yang di hasilkan besar-besar. Keunggulan lain pada perakaran yang kokoh dan daun yang tumbuh dapat dijadikan sebagai pakan ternak (Pioneer, 2006).

Teknik budidaya jagung yang dilakukan dalam penyuluhan jagung hibrida pioneer yaitu :

1. Penyiapan benih jagung dalam $1 \mathrm{Ha}$ dibutuhkan sebanyak 17 kilogram benih jagung hibrida.

2. Penyiapan lahan untuk penanaman dengan cara membajak lahan kemudian diratakan dengan cangkul.

3. Penanaman benih jagung pioneer dilakukan dengan tugal sedalam $5 \mathrm{~cm}$ untuk 1 butir benih setiap lubangnya. Setelah itu, menutup lubang tanam dengan pupuk kandang sapi.

4. Pemupukan dilakukan 3 kali yaitu pada saat penanaman awal, kemudian setelah tanaman jagung berumur 3 minggu, dan berumur 6 minggu. Adapun pupuk yang digunakan untuk penanaman awal yaitu pupuk ponska, setelah umur 3 minggu dan 6 minggu yaitu pupuk urea.

5. Penyiangan dilakukan sebelum dan sesudah pemupukan. Setelah itu dilakukan pembumbunan supaya pupuk dapat terserap dan aliran air nantinya dapat berjalan dengan lancar.

6. Pengairan dilakukan sebanyak 4 kali. Pertama ketika selesai penanaman. Setelah itu ketika tanaman jagung berumur 10 hari. Kemudian saat tanaman jagung berumur 25 hari, dan terakhir ketika tanaman jagung berumur 40 hari setelah tanam.

7. Pengendalian hama dan penyakit.

Panen dapat dilakukan setelah tanaman jagung berumur 95 sampai 110 hari (Pioneer, 2006).

\section{Jagung Varietas NK 33}

Jagung NK 33 merupakan varietas jagung hibrida yang paling populer dan sedang digemari di Indonesia, terutama di daerah Jawa Timur, Jawa Tengah, Lampung, Sumatera Utara,kalimantan, NTB, NTT dan Sulawesi. Bibit Jagung NK 33 diproduksi oleh Syngenta di Klaten, Jawa Tengah. Potensi hasil Panen Bisa mencapai hingga 12 ton/hektar jagung pipil kering (Darsono, 2002).

Bibit Jagung NK33 ini adalah teknologi pertanian masakini. Jenis Varietas Jagung NK 33 ini sangat tahan terhadap penyakit cocok untuk lahan pertanian kering dan lahan basah. Melalui penanaman jagung jenis hibrida NK 33, Para petani akan berpeluang besar untuk memperoleh hasil panen yang melimpah demi meningkatkan taraf hidup dan kesejahteraannya. Dengan adanya benih jagung hibrida NK 33 ini diharapkan petani mampu mengelola sumber daya yang tersedia secara terpadu dalam melakukan budidaya, dan mampu meningkatkan produksi hasil pertanian indonesia (Darsono, 2002).

\section{Jagung Varietas Pertiwi}

Jagung varietas pertiwi merupakan jenis jaguing hibrida yang di keluarkan sekitar tahun 2009, yang mempunyai keunggulan yaitu antara lain:

1. Tanaman kokoh.

2. Umur panen $\pm 102 \mathrm{HST}$.

3. Tinggi tanaman $\pm 222 \mathrm{~cm}$.

4. Potensil hasil $\pm 13,66$ ton/ha.

5. Rata-rata hasil $\pm 9,41$ ton/ha.

6. Warna biji orange/mutiara.

7. Lebih tahan bulai.

8. Cocok untuk tebon (hijauan-pakan) (Darsono, 2002)..

\section{E. Pupuk NPK Kujang}

Pupuk NPK Kujang dibuat dengan menggunakan bahan baku : Urea, Ammonium, ZA, DA, MAP, TSP, KCL, ZK, Rock Phospat, Zeolit+, Dolomit+, Kieserit+, TE, dan lain-lain. Selain bahan baku tersebut, NPK Kujang diberi tambahan bahan organik yang mengandung unsur hara organik sebanyak $\pm 20 \%$ dari total volume (Permadi dan Sunandar, 2013).

Keunggulan pupuk NPK Kujang, antara lain:

1. Lebih mudah dalam penggunaannya karena tidak perlu menambahkan pupuk lain, 
Website : http://agritek.unmermadiun.ac.id/index.php/agritek

2. Lebih lengkap dan seimbang kandungan unsur haranya.

3. Lebih seragampenyebaran unsure haranya.

4. Lebih efisien dalam penyerapan unsur haranya, karena bahan organik didalam pupuk NPK Kujang mempunyai KTK (Kapasitas Tukar Kation) yang tinggi (400-700 me/100 gr). Hal ini menyebabkan penghematan NPK Kujang.

5. Lebih efisien dalam penggunaan tenaga kerja dan waktu.

6. Lebih mudah dalam pengadaan dan penyimpanannya (Permadi dan Sunandar, 2013).

\section{III.BAHAN DAN METODE PENELITIAN}

\section{A. Waktu dan Tempat Penelitian}

Waktu penelitian dimulai bulan Oktober sampai dengan Desember 2018 di lahan perkebunan Jagung di Desa Pelanglor, Kecamatan Kedunggalar, Kabupaten Ngawi. Ketinggian lokasi \pm 75 m diatas permukaan laut.

\section{B. Bahan dan Alat Penelitian}

Alat yang digunakan dalam penelitian ini adalah: hand tractor, cangkul, tugal, meteran, tali plastik, timbangan, gembor, alat tulis, patok, papan nama, kamera digital. Alat-alat untuk analisis laboratorium. Bahan yang digunakan dalam penelitian ini adalah: benih jagung (varietas pioner, NK 33, Pertiwi), pupuk NPK Kujang, pupuk kandang, Herbisida merk Lindomin 865 SL untuk pengendalian gulma.

\section{Metode Penelitian}

Penelitian ini menggunakan metode faktorial dengan Rancangan Acak Kelompok (RAK) yang terdiri dari dua faktor dan 12 kombinasi perlakuan, diulang sebanyak 3 kali. Selanjutnya data yang diperoleh dari hasil pengamatan dan analisa secara statistik serta untuk membedakan antar perlakuan digunakan uji jarak berganda Duncan (DMRT) pada jenjang nyata 5\%.

Adapun masing-masing faktor tersebut :

1. FaktorPertama : Varietas (V) terdiri dari 3 taraf yaitu :

$$
\begin{array}{ll}
-\mathrm{V}_{1} & : \text { Pioner } \\
-\mathrm{V}_{2} & : \text { Nk } 33 \\
-\mathrm{V}_{3} & : \text { Pertiwi }
\end{array}
$$

2. FaktorKedua : Dosis pupuk NPK (P) terdiri dari 4 taraf, yaitu :

$$
\begin{array}{ll}
-\mathrm{P}_{0} & : \text { Tanpa pemupukan } \\
-\mathrm{P}_{1} & : 50 \mathrm{gram} / \text { petak } \\
-\mathrm{P}_{2} & : 100 \mathrm{gram} / \text { petak } \\
-\mathrm{P}_{3} & : 150 \mathrm{gram} / \text { petak }
\end{array}
$$

Sehingga diperoleh kombinasi perlakuan sebagai berikut :

$\begin{array}{lll}\text { V1P0 } & \text { V2P0 } & \text { V3P0 } \\ \text { V1P1 } & \text { V2P1 } & \text { V3P1 } \\ \text { V1P2 } & \text { V2P2 } & \text { V3P2 } \\ \text { V1P3 } & \text { V2P3 } & \text { V3P3 }\end{array}$

\section{Pelaksanaan Percobaan}

1. Persiapan Lahan

Pengolahan tanah dilakukan dengan mencangkul lahan kemudian dilanjutkan dengan meratakannya. Pembuatan petakpetak dilakukan dengan ukuran 1 × $3 \mathrm{~m}$ sebanyak 36 petak. Antar petak dibuat pematang selebar $70 \mathrm{~cm}$. Pengukuran $\mathrm{pH}$ tanah dan suhu untuk memastikan kelayakan tanah untuk tanaman jagung yang didapatkan sekitar 5,7 dan pengukuran dan suhu didapatkan $28^{\circ} \mathrm{C}$.

2. Penanaman

Penanaman dilakukan setelah kondisi tanah rata dan cukup air. Benih jagung perlubang ditanam dengan jarak 70 x $20 \mathrm{~cm}$.

3. Pemupukan

Pupuk NPK (sesuai dosis perlakuan) diberikan semua sebelum tanam (-1 HST) dengan cara disebar dan diolah untuk pencampuran. Campuran pupuk kandang dan sekam diberikan setelah tanam (1 HST) dengan cara disebar di permukaan tanah (sebagai mulsa) $(500 \mathrm{~kg} / \mathrm{ha}$ atau $100 \mathrm{~g} /$ petak).

Pupuk susulan I yaitu : P0 (tanpa pupuk NPK Kujang), P1 (NPK Kujang 50 g/petak), P2 (NPK Kujang 100 g/petak), serta P3 (NPK Kujang 150 g/petak) diberikan pada saat 10 HST sedangkan pupuk susulan II dengan dosis yang sama pada pupuk susulan I, diberikan pada saat 30 HST. Pupuk susulan I dan II diberikan secara Sidedressing yaitu ditebarkan secara alur disamping tanaman.

4. Pengendalian gulma

Pengendalian gulma dengan cara penyemprotan herbisida merk Lindomin 865 SL untuk pengendalian gulma langsung pada gulma. 
Website : http://agritek.unmermadiun.ac.id/index.php/agritek

\section{Pemanenan}

Pemanenan dilakukan pada saat tanaman jagung masak penuh yang ditandai dengan klobot yang mulai menguning dan biji jagung sudah keras pada umur $100 \mathrm{HST}$.

6. Pengamatan

a) Pertumbuhan

1) Tinggi tanaman $(\mathrm{cm})$

Tinggi tanaman di ukur dari permukaan tanah sampai ujung daun pada saat tanaman berumur 20 dan 40 hari setelah tanam.

2) Jumlah daun

Jumlah daun yang telah membuka pada umur 20 dan 40 hari setelah panen.

b) Produksi

1) Berat tongkol kering per petak (gram)

Diukur dengan menimbang seluruh jagung per petak setelah dipanen dan dikeringkan dengan sinar matahari sampai mencapai berat konstan dengan kadar air $14 \%$.

2) Berat tongkol kering per tanaman (gram)

Diukur dengan menimbang seluruh jagung per tanaman setelah dipanen dan dikeringkan dengan sinar matahari sampai mencapai berat konstan dengan kadar air $14 \%$.

3) Berat pipilan kering per petak (gram)

Diukur dengan menimbang pipilan kering setelah dipanen dan dikeringkan dengan sinar matahari sampai mencapai berat konstan dengan kadar air $14 \%$.

\section{IV.HASIL DAN PEMBAHASAN}

\section{A. Tinggi Tanaman (cm)}

Berdasarkan analisis sidik ragam, tidak terjadi interaksi antara varietas dan perlakuan pupuk NPK Kujang terhadap tinggi tanaman pada semua umur pengamatan.

Pengaruh perlakuan dosis pupuk NPK Kujang menunjukkan pengaruh nyata terhadap tinggi tanaman pada umur 20 dan 40 hst, sedangkan varietas jagung tidak menunjukkan pengaruh yang nyata pada umur 20 dan 40 hst.

Adapun rata-rata tinggi tanaman yang diperlakukan dengan beberapa varietas dan dosis pupuk NPK Kujang pada dua pengamatan umur adalah sebagai berikut:

Tabel 1. Pengaruh Varietas (V) dan Dosis Pupuk NPK Kujang (P) Terhadap Rata-Rata Tinggi Tanaman Umur 20 dan 40 hst.

\begin{tabular}{|l|c|c|}
\hline \multirow{2}{*}{ Perlakuan } & \multicolumn{2}{|c|}{ Rata-Rata Tinggi Tanaman (cm) } \\
\cline { 2 - 3 } & $\mathbf{2 0 ~ h s t}$ & $\mathbf{4 0}$ hst \\
\hline V1 & $23,53 \mathrm{a}$ & $47,80 \mathrm{a}$ \\
V2 & $23,75 \mathrm{a}$ & $48,71 \mathrm{a}$ \\
V3 & $23,93 \mathrm{a}$ & $50,59 \mathrm{a}$ \\
\hline P0 & & \\
P1 & $20,26 \mathrm{a}$ & $30,04 \mathrm{a}$ \\
P2 & $23,24 \mathrm{~b}$ & $49,92 \mathrm{~b}$ \\
P3 & $24,39 \mathrm{c}$ & $55,58 \mathrm{c}$ \\
\hline
\end{tabular}

Keterangan : Angka yang sama diikuti oleh huruf yang sama pada masing-masing kolom yang sama menunjukkan tidak ada beda nyata pada uji Duncan 5\%

Berdasar tabel di atas, tinggi tanaman rata-rata tertinggi pada perlakuan dosis pupuk NPK Kujang 150 g/petak (P3) pada umur $20 \mathrm{hst}: 27,06 \mathrm{~cm}$ dan $40 \mathrm{hst}$ : 60,60 cm yang berbeda nyata dengan semua parameter pengamatan (P0, P1 dan P2). Hal ini karena semua dosis pupuk NPK yang diberikan sesuai kebutuhan yang dibutuhkan tanaman sehingga berpengaruh nyata terhadap tinggi tanaman dan tampak terhadap pertumbuhan tanaman.

Perlakuan varietas jagung pada umur 20 hst dan 40 hst tidak menunjukkan beda nyata terhadap tinggi tanaman pada semua parameter pengamatan. Hal ini disebabkan karena varietas jagung yang digunakan dalam penelitian sama-sama jenis jagung hibrida yang memiliki keunggulan hampir sama terutama dalam hal ini pada kecepatan pertumbuhan.

\section{B. Jumlah Daun}

Berdasarkan analisis sidik ragam, tidak terjadi interaksi antara varietas dan dosis pupuk NPK Kujang terhadap jumlah daun pada semua umur pengamatan.

Pengaruh perlakuan dosis pupuk NPK Kujang menunjukkan pengaruh nyata terhadap jumlah daun pada umur 20 dan 40 hst, sedangkan varietas jagung tidak menunjukkan pengaruh yang nyata pada umur 20 dan 40 hst.

Adapun rata-rata jumlah daun yang diperlakukan dengan beberapa varietas dan dosis pemberian pupuk NPK Kujang pada dua pengamatan umur adalah sebagai berikut: 
Website : http://agritek.unmermadiun.ac.id/index.php/agritek

\begin{tabular}{|l|c|c|}
\hline \multirow{2}{*}{ Perlakuan } & \multicolumn{2}{|c|}{ Rata-Rata Jumlah Daun } \\
\cline { 2 - 3 } & $\mathbf{2 0 ~ h s t}$ & $\mathbf{4 0 ~ h s t}$ \\
\hline V1 & $7,75 \mathrm{a}$ & $9,83 \mathrm{a}$ \\
V2 & $7,92 \mathrm{a}$ & $10,08 \mathrm{a}$ \\
V3 & $8,00 \mathrm{a}$ & $10,08 \mathrm{a}$ \\
\hline P0 & & $9,00 \mathrm{a}$ \\
P1 & $5,67 \mathrm{a}$ & $9,78 \mathrm{~b}$ \\
P2 & $7,78 \mathrm{~b}$ & $10,11 \mathrm{~b}$ \\
P3 & $8,67 \mathrm{c}$ & $11,11 \mathrm{c}$ \\
\hline
\end{tabular}

Keterangan : Angka yang sama diikuti oleh huruf yang sama pada masing-masing kolom yang sama menunjukkan tidak ada beda nyata pada uji Duncan 5\%

Berdasar tabel di atas, jumlah daun rata-rata terbanyak pada perlakuan dosis pupuk NPK Kujang 150 g/petak (P3) pada umur 20 hst : 9,44 dan 40 hst : 11,11 yang berbeda nyata dengan semua parameter pengamatan (P0, P1 dan P2). Hal ini karena keunggulan pupuk Kujang yang salah satunya adalah memiliki unsur hara yang lengkap dan seimbang sehingga pertumbuhan tanaman jagung yang diukur dari jumlah daun menjadi berkembang lebih cepat.

Perlakuan varietas jagung pada umur 20 hst dan 40 hst tidak menunjukkan beda nyata terhadap jumlah daun pada semua parameter pengamatan.

\section{Berat tongkol kering per petak (gram)}

Berdasarkan analisis sidik ragam, tidak terjadi interaksi antara varietas dan perlakuan pupuk NPK Kujang terhadap bobot tongkol kering per petak pada pengamatan.

Pengaruh perlakuan dosis pupuk NPK Kujang menunjukkan pengaruh nyata terhadap bobot tongkol kering per petak tanaman jagung, sedangkan varietas jagung tidak menunjukkan pengaruh yang nyata pada tanaman jagung.

Adapun rata-rata bobot tongkol kering per petak yang diperlakukan dengan beberapa varietas dan dosis pemberian pupuk NPK Kujang pada pengamatan adalah sebagai berikut:

Tabel 3. Pengaruh Varietas (V) dan Dosis Pemberian Pupuk NPK Kujang (P) Terhadap Rata-Rata Bobot Tongkol Kering Per Petak (gram).

\begin{tabular}{|l|c|}
\hline \multicolumn{1}{|c|}{ Perlakuan } & Rata-Rata Bobot Tongkol Kering Per Petak (gram) \\
\hline V1 & $798,33 \mathrm{a}$ \\
V2 & $846,67 \mathrm{a}$ \\
V3 & $903,33 \mathrm{a}$ \\
\hline P0 & $526,67 \mathrm{a}$ \\
P1 & $624,44 \mathrm{a}$ \\
P2 & $868,89 \mathrm{~b}$ \\
P3 & $1377,78 \mathrm{c}$ \\
\hline
\end{tabular}

Keterangan : Angka yang sama diikuti oleh huruf yang sama pada masing-masing kolom yang sama menunjukkan tidak ada beda nyata pada uji Duncan 5\%

Berdasar tabel di atas, bobot tongkol kering per petak rata-rata terberat pada perlakuan dosis pupuk NPK Kujang 150 g/petak (P3), yaitu sebanyak 1377,78 gram yang berbeda nyata dengan semua parameter pengamatan (P0, P1 dan P2). Hal ini karena keunggulan pupuk Kujang yang salah satunya adalah memiliki unsur hara yang lengkap dan seimbang sehingga perkembangan tanaman jagung yang diukur dari bobot tongkol kering per petak menjadi berkembang lebih banyak.

Perlakuan varietas jagung tidak menunjukkan beda nyata terhadap bobot tongkol kering per petak pada semua parameter pengamatan.

\section{Berat tongkol kering per tanaman (gram)}

Berdasarkan analisis sidik ragam, terjadi interaksi antara varietas dan perlakuan pupuk NPK Kujang terhadap bobot tongkol kering per tanaman pada pengamatan.

Adapun interaksi yang nyata antara varietas dan perlakuan pupuk NPK Kujang terhadap bobot tongkol kering per tanaman pada semua umur pengamatan. 
Website : http://agritek.unmermadiun.ac.id/index.php/agritek

Tabel 5. Interaksi Varietas (V) dan Dosis Pemberian Pupuk NPK Kujang (P) Terhadap Rata-Rata Bobot Tongkol Kering Per Tanaman (gram).

\begin{tabular}{|c|c|}
\hline Kombinasi Perlakuan & Rata-Rata Bobot Tongkol Kering Per Tanaman (gram) \\
\hline V1P0 & $123,33 \mathrm{a}$ \\
\hline V2P0 & $130,00 \mathrm{a}$ \\
\hline V3P0 & $126,67 \mathrm{a}$ \\
\hline V1P1 & $203,33 \mathrm{ab}$ \\
\hline V2P1 & $210,00 \mathrm{ab}$ \\
\hline V3P1 & $260,00 \mathrm{ab}$ \\
\hline V1P2 & $433,33 \mathrm{~b}$ \\
\hline V2P2 & $473,33 \mathrm{~b}$ \\
\hline V3P2 & $566,67 \mathrm{~b}$ \\
\hline V1P3 & $714,00 \mathrm{~b}$ \\
\hline V2P3 & $715,33 \mathrm{~b}$ \\
\hline V3P3 & $720,00 \mathrm{c}$ \\
\hline
\end{tabular}

Keterangan : Angka yang sama diikuti oleh huruf yang sama pada masing-masing kolom yang sama menunjukkan tidak ada beda nyata pada uji Duncan 5\%

Berdasarkan tabel di atas perlakuan V3P3 berbeda nyata dengan semua parameter pengamatan dan merupakan hasil tertinggi yaitu 720,00 gram. Hal ini karena pemberian pupuk Kujang 150 g/petak yang dikombinasikan dengan varietas jagung Pertiwi memberikan hasil yang optimal terutama karena pupuk NPK Kujang memiliki memiliki unsur hara yang lengkap dan seimbang, sehingga memberikan hasil yang baik.

\section{E. Berat pipilan kering per petak (gram)}

Berdasarkan analisis sidik ragam, tidak terjadi interaksi antara varietas dan perlakuan pupuk NPK Kujang terhadap bobot pipilan kering per petak pada pengamatan.

Pengaruh perlakuan varietas dan dosis pupuk NPK Kujang menunjukkan pengaruh nyata terhadap bobot pipilan kering per petak (gram).

Adapun rata-rata bobot pipilan kering per petak yang diperlakukan dengan beberapa varietas dan dosis pemberian pupuk NPK Kujang pada pengamatan adalah sebagai berikut:

Tabel 6. Pengaruh Varietas (V) dan Dosis Pemberian Pupuk NPK Kujang (P) Terhadap Rata-Rata Bobot Pipilan Kering Per Petak (gram).

\begin{tabular}{|l|c|}
\hline \multirow{1}{*}{ Perlakuan } & Rata-Rata Bobot Pipilan Kering Per Petak (gram) \\
& \\
\hline V1 & $691,67 \mathrm{a}$ \\
V2 & $815,83 \mathrm{ab}$ \\
V3 & $876.67 \mathrm{~b}$ \\
\hline P0 & $425,56 \mathrm{a}$ \\
P1 & $524,44 \mathrm{a}$ \\
P2 & $635,56 \mathrm{~b}$ \\
P3 & $1593,33 \mathrm{c}$ \\
\hline
\end{tabular}

Keterangan : Angka yang sama diikuti oleh huruf yang sama pada masing-masing kolom yang sama menunjukkan tidak ada beda nyata pada uji Duncan 5\%

Berdasar tabel di atas, bobot pipilan kering per petak rata-rata terberat pada perlakuan dosis pupuk NPK Kujang 150 g/petak (P3), yaitu sebanyak 1593,33 gram yang berbeda nyata dengan semua parameter pengamatan (P0, P1 dan P2). Hal ini karena keunggulan pupuk Kujang yang salah satunya adalah memiliki unsur hara yang lengkap dan seimbang sehingga perkembangan tanaman jagung yang diukur dari bobot pipilan kering per petak menjadi berkembang lebih optimal. Sedangkan varietas pertiwi (V3) memberikan rata-rata tertinggi : 876,67 gram yang berbeda nyata dengan V1 dan tidak berbeda nyata dengan V2.

\section{KESIMPULAN DAN SARAN}

\section{A. Kesimpulan}

1. Terdapat interaksi antara varietas dan dosis pemberian pupuk NPK terhadap rata-rata bobot tongkol kering per tanaman (gram).

2. Perlakuan varietas Pertiwi (V3) dan dosis pemberian pupuk NPK Kujang 150 g/petak (P3) memberikan rata-rata hasil tertinggi pada semua parameter pengamatan.

3. Kombinasi perlakuan V3P3 (varietas pertiwi dan dosis pemberian pupuk NPK Kujang 150 g/petak) memberikan hasil panen terbaik. 
Website : http://agritek.unmermadiun.ac.id/index.php/agritek

\section{B. Saran}

Dari hasil penelitian yang dilakukan, perlu kiranya dilakukan penelitian lanjutan dengan menerapkan beberapa teknik dalam pemupukan sampai pada masa generatif dengan dosis pupuk yang berbeda, serta dilakukan pada lahan, musim dan dengan menggunakan varietas yang berbeda pula, sehingga dapat diperoleh informasi yang lebih akurat terhadap pertumbuhan dan produksi jagung (Zea mays L.).

\section{VI.DAFTAR PUSTAKA}

Astiana. S, 2004. Penggunaan Bahan Mineral Zeolit Sebagai Campuran Pupuk Zeolit-Urea Tablet, Departemen Ilmu Tanah dan Sumber Daya lahan, Fakultas Pertanian, IPB, Bogor.

Bachrein, S., 2001. Peningkatan Efisiensi Pemupukan Dengan Penggunaan Mineral Zeolit Pada Padi Sawah Berpengairan. http://jabar.litbang.deptan.go.id, Barbarick, K.A, and H.J. Pirelli, 2010. Agronomic and Hoticultural Uses of Zeolite Review, Westview Press. Boulder, Colorado.

Dewi Lestari, 2010. "Kajian Modifikasi dan Karakterisasi Zeolit Alam Dari Berbagai Negara", Proseding Nasional Kimia dan Pendidikan Kimia.

Estiaty, L. M., Suwardi, I. Maruya dan S.D Fatimah, 2006. "Pengaruh Zeolit dan Pupuk Kandang Terhadap Unsur Hara". Jurnal Zeolit Indonesia, Vol.5(1). Georgiev, et al., 2009. "Syntetic Zeolit-Structure Classification, Currebt Trendsin Zeolit Synthetis", International Science Conference,Volume VII, Bulgaria. Ina Hasanah, 2007. Bercocok Tanam Padi, Azka Mulia Media, Jakarta.

Kamarudin et al., 2008. "Derajat Kristalisasi sebagai Fungsi Waktu Ageing dan Waktu Kristalisasi pada Sintesis Zeolit A dengan Radiasi Gelombang Mikro", Jurnal Sains dan Terapan Kimia. Vol. 1, No. 1.

Koswara, 2007, Pengolahan Umbi Non-Konvensional (Ganyong, Garut, Gadung, Gembili, dan Uwi), Ebook pangan.com., Jakarta.

Lodish, Berk, Matsudaira, Kaiser, Krieger, Scott et al., 2003. Molecular cell biology. 5th ed. New York: W H Freeman \& Co.

Suharsimi Arikunto, 2006. Prosedur Penelitian Suatu Pendekatan Praktek, Rineka Cipta: Jakarta.

Sunarto, 2014. Pemuliaan Tanaman, Cetakan ke-2, IKIP Semarang Press, Yogyakarta.

Sunardi dan Abdullah, 2007. "Konversi abu layang batubara menjadi zeolit dan pemanfaatannya sebagai adsorben merkuri (II)". Jurnal Sains dan Terapan Kimia, Vol.1, No. 1.

Suwardi, 2002. "Pemanfaatan Zeolit untuk Meningkatkan Produksi Tanaman Pangan, Peternakan, dan Perikanan", Makalah Teknologi Aplikasi Pertanian Bogor, IPB, Bogor.

Wittayakun, J., Artkla, S., Grisdanurak, N dan Neramittagapong, S., 2008. "Characterization and Catalytic Performance on Transesterification of Palm Olein Potasium Oxide Supported on RH-MCM-41 from Rice Husk Silica”, Journal Sci. Technol., Vol. 15(2).

Wongkasemjit, S., M. Sathupunya dan Gulari, 2002. "ANA and GIS zeolite synthesis directly from alumatrane and silatrane by sol-gel process and microwave technique", Journal of the European Ceramic Society, vol 2.

Yulianti, Fitri dkk., 2011. "Pengaruh Katalis Asam (H2SO4) dan Suhu Reaksi pada Reaksi Esterifikasi Minyak Biji Karet (Hevea brasiliensis) menjadi Biodiesel", Skripsi, Jurusan Teknik Kimia Fakultas Teknologi Industri ITS Surabaya. Surabaya.

Yusuf, A dan Harnowo, D., 2010. Teknologi Budidaya Padi sawah Mendukung Sl-PTT. BPTP. Sumatera Utara.

Zaini, Z., W.S. Diah, dan M. Syam, 2004. Pengelolaan Tanaman Terpadu Padi Sawah Meningkatkan Hasil dan Pendapatan Menjaga Kelestarian Lingkungan, Badan Pengkajian dan Pengembangan Teknologi Pertanian Bogor. 